\title{
Perubahan Sosial Ekonomi Masyarakat Petani Pasca Banjir Bandang Di Desa Meli Kecamatan Baebunta Kabupaten Luwu Utara
}

\author{
Nur Hawa Jamin ${ }^{1}$ Risfaisal $^{2}$ \\ 1Mahasiswa Pendidikan Sosiologi, Universitas Muhammadiyah Makassar \\ Email: nurhawajamin99@gmail.com \\ 2Program Studi Pendidikan Sosiologi, Universitas Muhammadiyah Makassar \\ Email: risfaisal@unismuh.ac.id
}

\begin{abstract}
Socio-Economic Change is the difference in situations and conditions from what is usually done by the community in meeting their daily needs as a result of several factors behind these changes, for example external factors, namely the occurrence of natural disasters such as flash floods that sweep across the community's rice fields so that people have to relocate their jobs to meet their needs. necessities of life. The main purpose of this study is to find out about the impact and solutions to overcome the socioeconomic conditions of rice farmers before and after the flash flood disaster in Meli Village, Baebunta District, North Luwu Regency, South Sulawesi Province. The research method used is qualitative research. The results of the research in the field indicate that the large volume of banjir bandang causes a lot of losses and damage to the people of Meli Village. See the impact experienced. The community and government have tried to carry out the process of economic recovery for the Meli Village community individually and also in collaboration.
\end{abstract}

Keywords : Flood impact; Social change; Economy

\begin{abstract}
Abstrak
Perubahan Sosial Ekonomi adalah Perbedaan situasi dan kondisi dari biasanya yang dilakukan oleh masyarakat dalam memenuhi kebutuhan hidupnya akibat dari beberapa faktor yang melatarbelakangi perubahan tersebut misalnya faktor dari luar yaitu terjadinya bencana alam seperti banjir bandang yang menyapu seluruh persawahan masyarakat sehingga masyarakat harus melakukan relokasi pekerjaan untuk memenuhi kebutuhan hidupnya. tujuan utama dari penelitian ini untuk mencari tahu tentang dampak dan solusi mengatasi kondisi sosial ekonomi petani sawah sebelum dan sesudah terjadinya bencana banjir bandang di Desa Meli Kecamatan Baebunta Kabupaten Luwu Utara Provinsi Sulawesi Selatan. Adapun metode penelitian yang digunakan adalah penelitian kualitatif. Hasil penelitian di lapangan menunjukkan bahwa besarnya volume banjir bandang membuat banyak nya kerugian dan kerusakan yang dialami masyarakat Desa Meli. Melihat dampak yang dialami. Masyarakat dan pemerintah telah berupaya melakukan proses pemulihan ekonomi masyarakat Desa Meli secara pribadi dan juga bekerja sama.
\end{abstract}

Kata Kunci : Dampak Banjir; Perubahan Sosial; Ekonomi 


\section{PENDAHULUAN}

Salah satu kabupaten di Provinsi Sulawesi Selatan di pertengahan tahun 2020 telah mengalami perubahan sosial ekonomi akibat bencana alam, yaitu Kabupaten Luwu Utara. Secara geografis Kabupaten Luwu Utara terletak pada $01053^{\prime} 19^{\prime \prime}$ - $02^{\circ} 55^{\prime} 36^{\prime \prime}$ Lintang Selatan, dan $119^{\circ} 47^{\prime} 46^{\prime \prime}-120^{\circ} 37^{\prime}$ 44 Bujur Timur, yang terdiri dari 11 Kecamatan dan 171 Desa dan terdapat 8 sungai besar. Pada tanggal 13 juli 2020 telah terjadi peristiwa banjir bandang dari 3 sungai besar yang berdampak pada 9 Desa dari 4 Kecamatan diantaranya Desa Pararra, Sabbang, Meli, Radda, Maipi, Balebo, Masamba, Laba dan Malangke. Kejadian tersebut telah banyak mengakibatkan kerusakan lingkungan dan kerugian perekonomian terutama daerah persawahan dan perkebunan karena ratarata lokasinya berada di pinggir sungai. Selain menyebabkan kerusakan, kejadian banjir bandang ini juga telah menelan kurang lebih 50 korban jiwa dari 3 kecamatan. Kerusakan dan korban jiwa terbanyak berada pada kecamatan Baebunta.

Desa Meli merupakan salah satu desa yang terletak di Kecamatan Baebunta Kabupaten Luwu Utara yang termasuk daerah dataran tinggi serta memiliki 1.771 penduduk dimana sebagian besar kepala keluarga di desa Meli berprofesi sebagai petani padi sawah. Desa Meli juga terkena dampak banjir bandang cukup parah, karena dari ke 3 sungai yang mengalami banjir bandang sungai meli atau biasa dikenal masyarakat sebagai sungai radda ini yang paling besar volume air nya, dan kerusakan yang ditimbulkan sangat besar.

Dampak dari kejadian banjir bandang ini menyebabkan cukup besar perubahan sosial yang dirasakan masyarakat Desa Meli terutama pada kondisi ekonomi dan psikologis nya. Karena Masyarakat Desa Meli Merupakan masyarakat yang mayoritas hidup sebagai petani sawah dengan tingkat pendidikan mayoritas SD, SMP dan SMA.

Sebagian besar masyarakat desa meli telah melakukan Relokasi ketempat yang lebih tinggi dan jauh dari aliran sungai untuk meminimalisir kerugian jika kemungkinan terjadinya bencana susulan.
Proses relokasi ini juga membuat masyarakat mengalami perubahan sosial, dimana masyarakat harus mampu menyesuaikan diri dengan lingkungan sosial baru dengan tetangga baru dan situasi yang berbeda dari sebelumnya.

Perubahan sosial yang terlihat dari kejadian banjir bandang di Desa Meli yaitu Sebelum terjadinya banjir bandang, masyarakat tani di Desa Meli masih memiliki pekerjaan tetap sebagai petani sawah dimana mereka dapat mencukupi kebutuhan hidupnya dari hasil panen sebagai petani sawah bahkan bisa menyekolahkan anak-anak mereka tanpa bingung untuk mendapatkan biaya. Akan Tetapi setelah terjadinya banjir bandang pada tanggal 13 Juli 2020, masyarakat tani di Desa Meli banyak kehilangan pekerjaan tetap nya karena lahan yang selama ini digarap tertimbun oleh material berupa lumpur dan batu. hal ini berdampak pada ekonomi masyarakat petani sawah terutama mereka yang berpenghasilan rendah dan kurangnya tingkat pendidikan untuk mencari pekerjaan lain sebagai peralihan dalam memenuhi perekonomian dan pendidikan anaknya.

Teori dalam penelitian ini menggunakan Teori Fungsional Strruktural, Teori ini memiliki asumsi utama yaitu melihat masyarakat sebagai sebuah sistem yang di dalamnya terdapat subsistem. Teori ini mengambil analogi masyarakat sebagai salah satu sistem organik (makhluk hidup). Alasan peneliti mengangkat teori ini sebagai teori pendukung kareena penjelasan dalam teori ini dapat menggambarkan kondisi subjek dan objek yang akan peneliti lakukan dimana dalam teori Fungsionalis dijelaskan bahwa kehidupan sosial yang berubah karena salah satu sistem sosial mengalami disfungsi sehingga mempengaruhi sistem lainnya, dan kondisi sosial yang mengalami permasalahan dalam penelitian ini adalah keadaan ekonomi masyarakat Desa Meli akibat banjir bandang, dimana ekonomi merupakan inti dalam tatanan sosial dalam kehidupan sosial masyarakat terutama di dalam tatanan rumah tangga, jika ekonomi yang bermasalah maka sistem sosial lainnya akan berpengaruh seperti yang dirasakan oleh beberapa kepala keluarga yang ada di 
Desa Meli karena sulit dalam ekonomi sehingga mempengaruhi pendidikan anakanak nya dan mental kepala keluarga akibat kesulitan menyesuaikan kondisi dengan keadaan.

Konsep penting dalam teori ini adalah struktur dan fungsi, seperti yang dikemukakan oleh salah satu teoritikus yang termasuk dalam teori ini adalah Talcot Parsons (1974) dalam Nursalam Dkk (2016) yaitu studi mengenai perubahan sosial harus dimulai dengan struktur sosial terlebih dahulu. Teori ini dimulai dengan empat fungsi penting untuk semua sistem "tindakan" yang disebut dengan AGIL

1. Adaptasi, Fungsi ini merupakan sistem tingkah laku, dimana individu harus mampu menyesuaikan diri dengan lingkungannya, seperti yang dilakukan masyarakat Desa Meli yang melakukan relokasi tempat tinggal dan pekerjaan akibat banjir bandang yang menimpa mereka

2. Goal attainment/ Pencapaian tujuan adalah suatu sistem selayaknya diorientasikan untuk mencapai tujuan, seperti yang terlihat dari masyarakat Desa Meli mereka melakukan relokasi dengan tujuan untuk meminimalisir kerugian dari kemungkinan terjadinya bencana susulan karena melihat kondisi fisik geografis daerah hulu sungai yang sudah tidak utuh dan untuk memperbaiki perekonomian mereka.

3. Integration/ Integrasi yaitu kerja sama antara beberapa elemen yang menjadi komponen nya, seperti yang terlihat pada masyarakat Desa Meli dimana mereka melakukan kerja sama untuk memulihkan perekonomian Desa dan Masyarakat salah satu nya gotong royong memperbaiki infrastruktur umum dan mendirikan beberapa kelompok tani untuk menunjang potensi masyarakat dengan penyesuaian kondisi pendidikan masyarakat.

4. Laten pattern/ Pemeliharaan pola yaitu sistem yang mengatur kehidupan masyarakat, Seperti yang terdapat pada masyarakat Desa Meli yaitu kerja sama antara masayarakat dan pemerintah sangat di perlukan untuk mencapai target pemulihan ekonomi desa dan Masyarakat.

\section{METODE PENELITIAN}

Jenis penelitian yang digunakan dalam penelitian ini berupa penelitian Campuran (Mixed Method). Menurut Sugiyono (2016), metode penelitian campuran merupakan metode penelitian dengan mengkombinasikan antara dua metode penelitian kualitatif dan kuantitatif dalam suatu kegiatan penelitian sehingga akan diperoleh data yang lebih komprehensif, valid, reliabel, dan objektif. Metode penelitian campuran ini (Mixed Methods) menggunakan model penelitian campuran strategi terpadu bersama-sama (concurrent embedded strategy), yaitu metode pengumpulan data yang diawali oleh kuantitatif kemuadian kualitatif atau sebaliknya kualitatif kemudian kuantitatif atau dilakukan secara bersamaan kemudian melakukan perbandingan atau menghubungkan data yang diperoleh lalu di interpretasikan.

Alasan memilih jenis penelitian ini karena ingin menghasilkan fakta yang lebih banyak dalam meneliti masalah penelitian, dengan tujuan untuk melengkapi gambaran hasil studi mengenai fenomena yang diteliti dan untuk memperkuat analisis penelitian dari kejadian banjir bandang yang terjadi di Desa Meli Kecamatan Baebunta Kabupaten Luwu Utara. Pendekatan yang digunakan dalam penelitian ini adalah pendekatan mixed method yaitu menggabungkan 2 pendekatan dari penelitian kuantitatif dan kualitatif dengan menggunakan analisis persentase. Pendekatan yang dimaksud disini adalah pengumpulan data data melalui lembar angket yang di isi oleh informan dengan jawaban yang pasti untuk memahami kejadian atau fenomena yang mempengaruhi subjek, dalam penelitian ini peneliti telah memperoleh hasil berupa data-data kuesioner dan hasil mewawancarai narasumber yang menjadi subjek utama dalam penelitian ini.

Alasan Peneliti memilih jenis pendekatan ini yaitu untuk untuk memberikan gambaran secara mendetail dan menceritakan berbagai latar belakang atau kondisi seseorang khusus nya korban banjir terkait kejadian banjir bandang yang dampaknya sangat dirasakan oleh 
masyarakat petani sawah di Desa Meli, Kecamatan Baebunta, Kabupaten Luwu Utara terutama pada dampak nya terhadap perekonomian masyarakat dan bagaimana mengatasi perubahan yang mereka rasakan.

Penentuan informan dari data kuantitatif yang digunakan dalam penelitian ini adalah populasi dan sampel dengan Simple Random Sampling merupakan teknik pengmabilan sampel yang dilakukan secara acak tanpa memerhatikan strata yang diambil dalam populasi tersebut (Dattalo,2008 dalam martono 2016). Sedangkan teknik penentun informan dari data kualitatif yang di gunakan dalam penelitian ini adalah Purposive Sampling. Informan dalam penelitian ini ditentukan berdasarkan orang-orang yang memiliki kriteria pengetahuan tentang peristiwa banjir dan merasakan kondisi sosial ekonomi pasca bencana banjir bandang.

Teknik pengumpulan data yang digunakan dalam penelitian ini melalui metode wawancara, observasi, dokumentasi dan kuesioner. Teknik keabsahan data adalah proses mengtringulasikan data yang terdiri dari data Kuesioner atau angket, observasi, wawancara, dan dokumen. Dalam setiap penelitian diperlukan suatu kebenaran atau keabsahan data agar penelitian memenuhi kriteria validitas dan reliabilitas. Adapun Teknik keabsahan data dalam penelitian ini yaitu Ketekunan dan Triangulasi (data, peneliti, teori dan metode)

\section{HASIL DAN PEMBAHASAN}

1. Dampak sosial ekonomi pasca banjir bandang terhadap petani sawah di Desa Meli Kecamatan Baebunta Kabupaten Luwu Utara

\section{a. Ekonomi}

Beberapa daerah di kabupaten Luwu utara telah terkena dampak banjir bandang pada 13 juli 2020 sampai saat ini 2021 sebagian dari mereka masih merasakan dampak nya. Kejadian banjir bandang itu baru pertama kali terjadi di Luwu Utara dan begitu besar kerusakan dan kerugian yang ditimbulkan. Dampak dari kejadian banjir bandang terhadap masyarakat Desa Meli terbagi menjadi tiga kategori dari 86 sampel dimana pada kelompok dampak kecil sebanyak 11 orang dengan presentasi $12,8 \%$, untuk kelompok dampak sedang sebanyak 27 orang dengan persentase $31,4 \%$ dan untuk kelompok dampak besar sebanyak 48 orang dengan persentase 55,8\%. Maka berdasarkan data tersebut dapat disimpulkan bahwa dampak terbanyak yang dialami masyarakat Desa Meli adalah dampak yang besar sebanyak 48 orang dengan persentase 55,8\% dan dampak terendah yang dialami masyarakat Desa Meli adalah dampak yang kecil sebanyak 11 orang dengan presentasi 12,8 $\%$.

\section{b. Psikolosgis dan Pendidikan}

Dampak banjir bandang selain mengarah ke kerusakan dan kerugian, juga senantiasa mengakibatkan dampak psikologis seperti menimbulkan rasa trauma dan juga sempat menghambat pendidikan anak-anak korban karena kondisi fisik sekolah atau kondisi sosial lainnya seperti yang diperoleh dari hasil analisis data kuesioner yang di isi oleh 60 sampel. Kesimpulan diatas adalah banjir bandang menyebabkan dampak psikologis yaitu trauma bagi sebagian masyarakat Desa Meli, dimana dampak trauma terbanyak berasal dari anak-anak sebanyak 16 orang dari 86 sampel dengan persentase $18,6 \%$ dan dampak trauma terkecil ada pada orang dewasa/orang tua dengan jumlah 12 orang dari 86 sampel dengan persentase $13,9 \%$, jadi secara keseluruhan yang mengalami dampak psikologis pasca banjir bandang sebanyak 28 orang dari 86 sampel dengan persentase $32,6 \%$ dari $100 \%$.

Berdasarkan data diatas tentang
dampak banjir bandang terhadap
pendidikan anak-anak di Desa Melipasca
Banjir bandang menunjukkan bahwa
kelompok data TK-SD sebanyak 12 orang
dari 86 sampel dengan persentase $14 \%$,
kelompok SMP sebanyak 6 orang dari 86
sampel dengan persentase $7 \%$, kelompok
SMA sebanyak 5 orang dari 86 sampel
dengan persentase 5,8\% dan kelompok
kuliah sebanyak 3 orang dari 86 sampel
dengan persentase 3,5\%, dan yang tidak
mengalami dampak pendidikan sebanyak

Berdasarkan data diatas tentang dampak banjir bandang terhadap pendidikan anak-anak di Desa Melipasca Banjir bandang menunjukkan bahwa kelompok data TK-SD sebanyak 12 orang dari 86 sampel dengan persentase 14\%, kelompok SMP sebanyak 6 orang dari 86 sampel dengan persentase $7 \%$, kelompok SMA sebanyak 5 orang dari 86 sampel kuliah sebanyak 3 orang dari 86 sampel mengalami dampak pendidikan sebanyak 
60 orang dari 86 sampel dengan persentase $69,7 \%$ jadi kesimpulannya keseluruhan jumlah orang yang merasakan dampak pendidikan sebanyak 26 orang dari 86 sampel dengan persentase $30,3 \%$.

Berdasarkan beberapa hasil wawancara yang di peroleh yaitu Adapun pengaruh banjir bandang yang dirasakan masyarakat Desa Meli yaitu berubahnya kondisi ekonomi, perubahan mata pencaharian, pendapatan berkurang dan melakukan relokasi. Keadaan tersebut dialami oleh masyarakat desa Meli yang memiliki sumber mata pencaharian yang berbeda-beda, mulai dari yang berpenghasilan dari hasil padi sawah, hasil kelapa sawit dan hasil pertanian lainnya bahkan sampai terdampak pada beberapa pedagang.

Adapun Perubahan sosial yang terlihat dari kejadian banjir bandang di Desa Meli yaitu Sebelum terjadinya banjir bandang, masyarakat tani di Desa Meli masih memiliki pekerjaan tetap sebagai petani sawah dimana mereka dapat mencukupi kebutuhan hidupnya dari hasil panen sebagai petani sawah bahkan bisa menyekolahkan anak-anak mereka tanpa bingung untuk mendapatkan biaya. Akan Tetapi setelah terjadinya banjir bandang pada tanggal 13 Juli 2020, masyarakat tani di Desa Meli banyak kehilangan pekerjaan tetap nya karena lahan yang selama ini digarap tertimbun oleh material berupa lumpur dan batu. hal ini berdampak pada ekonomi masyarakat petani sawah terutama mereka yang berpenghasilan rendah dan kurangnya tingkat pendidikan untuk mencari pekerjaan lain sebagai peralihan dalam memenuhi perekonomian dan pendidikan anaknya. Dengan berbagai dampak yang dirasakan masyarakat Desa Meli terutama para petani, mendorongnya untuk mengambil langkah dalam proses pemulihan kondisi ekonomi yang mereka alami.

Perubahan yang terjadi pada kondisi sosial ekonomi masyarakat desa Meli membuat masyarakat sadar bahwa apapun kondisi nya mereka memang akan merasakan perubahan baik itu perubahan besar atau kecil.
Sebagaimana dalam Teori fungsional saat salah satu sistem sosial dalam masyarakat mengalami disfungsi maka akan terjadinya perubahan sosial baik itu maju atau mundur sesuai dengan sistem yang mengalami disfungsi. Seperti yang dialami masyarakat Desa Meli dimana ekonomi mereka terutama masyarakat petani sawah mengalami kemunduran karena sumber mata pencaharian mereka diterjang banjir sehingga harus melakukan pemulihan ekonomi yang membutuhkan waktu dan tenaga untuk memulai dari awal, sehingga hal tersebut sangat menjadi permasalahan serius bagi setiap kepala keluarga yang keterbatasan modal dan pendidikan. Dari masalah ekonomi akan mempengaruhi kehidupan sosial lainnya karena keadaan ekonomi menjadi induk atau inti dalam struktur tatanan kehidupan sosial.

\section{Solusi mengatasi dampak sosial ekonomi pasca banjir bandang terhadap masyarakat petani sawah di Desa Meli Kecamatan Baebunta Kabupaten Luwu Utara}

Banyaknya permasalahan yang dihadapi sebagian besar masyarakat Desa Meli terkait kehidupan sosial mereka. Mendorong masyarakat Desa Meli untuk melakukan upaya pemulihan kondisi sosial mereka, baik dari mereka pribadi sampai pada upaya pemerintah dalam menangani permasalahan sosial masyarakat Desa Meli

\section{A. Masyarakat}

Upaya pemulihan ekonomi bagi petani paling banyak dilakukan adalah kelompok upaya peralihan pekerjaan sebagai buruh tani sebanyak 39 orang dari 86 sampel petani dengan persentase $45,3 \%$ sedangkan kelompok upaya pemulihan ekonomi paling rendah adalah kelompok perbaikan/peralihan lahan sebanyak 10 orang dari 86 sampel dengan persentase $11,7 \%$.

\section{b. Pemerintah}

Upaya pemerintah dalam memberikan bantuan kepada masyarakat yang telah mendapat bantuan sebanyak 58 orang dari 86 sampel dengan persentase $67,4 \%$ dan yang sementara proses sebanyak 
28 orang dari 86 sampel dengan persentase $32,6 \%$ dan yang tidak menerima bantuan dari pemerintah tidak ada.

Upaya pemerintah dalam kategori baik dipilih sebanyak 67 orang dari 86 sampel dengan persentase $78 \%$ dan yang memilih lumayan sebanyak 19 orang dari 86 sampel dengan persentase $22 \%$ dan yang memilih tidak sebanyak 0 .

Upaya masyarakat desa Meli dalam mengatasi dampak sosial akibat banjir bandang adalah melakukan peralihan. Peralihan disini mulai dari relokasi tempat tinggal ke tempat yang aman, sampai pada peralihan pekerjaan yang sesuai dengan kemampuan mereka. Kebanyakan kepala keluarga yang terkena dampak banjir di Desa Meli memiliki tingkat pendidikan yang kurang, sehingga proses pemulihan ekonomi yang mereka kerjakan adalah kembali ke pengelolaan hasil alam. Kurangnya pengetahuan dan pengalaman di sektor lain selain menjadi petani, membuat beberapa kepala keluarga yang kehilangan sumber mata pencahariannya, sulit mendapat pekerjaan sehingga mereka harus mencari pekerjaan yang mudah mereka akes salah satu sumber mata pencaharian yang saat ini dilakukan oleh sebagian masyarakat desa Meli yaitu menjadi buruh harian di lahan kebun kelapa sawit orang lain, di samping itu mereka juga ada yang berkebun sayur di sela sela waktu yang tidak digunakan menjadi buruh harian, karena buruh harian tidak selalu tersedia paling tidak 3 kali seminggu dengan upah yang tidak seberapa.

$$
\text { Upaya dalam mengatasi }
$$

permasalahan sosial ekonomi yang telah dilakukan masyarakat dan pemerintah dalam proses pemulihan ekonomi akibat banjir bandang merupakan wujud dari berdampingan perubahan dengan kondisi masyarakat, sebagaimana dalam Teori Fungsional yang dikemukakan oleh Talcot Persons dalam AGIL, Teori ini Melihat bahwa dalam kehidupan sosial ada struktur yang harus dijaga, jika salah satu struktur mengalami disfungsi terutama ekonomi maka akan mempengaruhi fungsi struktur lainnya oleh karena itu masyarakat dan pemerintah harus bekerja sama guna menjaga dan memperbaiki jika salah satu struktur dalam masyarakat mengalami masalah seperti pada masyarakat desa Meli yang mengalami permasalahan sosial Ekonomi yang membuat banyak dampak dan kerugian bagi masyarakat terutama kepala keluarga dan anak-anak, namun dengan adanya kerja sama antara pemerintah dan masyarakat, membuat perekonomian mulai normal sedikit demi sedikit melalui beberapa program, dari pemerintah yang dijalankan masyarakat.

\section{KESIMPULAN}

1. Dampak yang ditimbulkan dari banjir bandang membawa perubahan sosial dalam kehidupan masyarakat desa Meli terutama bagi petani, yang kehilangan tempat tinggal dan sumber mata pencaharian sehingga mereka harus melakukan relokasi tempat tinggal dan peralihan sumber mata pencaharian, yang dulu nya bekerja sebagai petani sawah di lahan sendiri kini mereka harus menjadi buruh harian di lahan orang lain. Kurangnya pendidikan kepala keluarga di desa Meli membuat mereka sulit dalam mencari pekerjaan lain, sehingga jalan satu satunya adalah kembali mengelola alam namun dalam konteks yang berbeda, dari hasil tani padi menjadi buruh sawit.

2. Segala upaya pemulihan yang dilakukan oleh masyarakat bersama dengan pemerintah. Dari masyarakat sendiri upaya yang dilakukan adalah melakukan relokasi tempat tinggal dan peralihan pekerjaan yang sesuai dengan latar belakang kemampuan setiap kepala keluarga salah satunya adalah menjadi buruh harian kelapa sawit. Pemerintah juga turut membantu masyarakat desa Meli dalam proses pemulihan dengan menyediakan hunian sementara sampai hunian tetap serta mengembangkan sumber daya manusia dengan program membuat kelompok tani bagi masyarakat yang terkena dampak banjir bandang. 


\section{DAFTAR PUSTAKA}

Buku :

Ahmadi, Rulam. (2014). Metodologi penelitian kualitatif. Yogyakarta: ArRuzz media

Ajat, Rukajat. (2018). Pendekatan Penelitian Kualitatif (Qualitative Research Approarch). Karawang: Deepublish .

Creswell, John W. (2019). research design pendekatan metode kualitatif, kuantitatif, dan campuran. Yogyakarta: Pustaka pelajar

Hadean, Sharma. 2011. Refleksi Masamba Affair. Yogyakarta: Yayasan Benua

Martono, Nanang. (2012). Sosiologi perubahan sosial perspektif klasik, modern, posmodern, dan poskolonial. Jakarta: Pt Raja Grafindo Persada

Nugrahani, Farida. (2014). Metode Penelitian Kualitatif Dalam Bahasa Indonesia. Surakarta: Univet Bantara.

Nursalam, Dkk. (2016). Teori sosiologi klasik, modern, postmodern, saintifik, hermeneutic, kritis, evaluatif dan integratif. Yogyakarta; Writing Revolution

Pendidikan Sosiologi FKIP Unismuh Makassar. (2019). Panduan Penelitian Skripsi Dan Skripsi.Makassar. Makassar: Pendidikan Sosiologi FKIP Unismuh Makassar

Rosyidi, Suherman. (2017). Pengantar Teori Ekonomi Pendekatan Kepada Teori Ekonomi Mikro \& Makro. Jakarta: RajaGrafindo Persada

Sugiyono. (2013). Metode penelitian kuantitatif, kualitatif, dan $R \& D$. Bandung; Alfabeta

Upe, Ambo. (2010). Tradisi Aliran dalam sosiologi dari filosofi positivistik ke post positivistik. Jakarta : $\mathrm{Pt}$ RajaGrafindo Persada

Jurnal :

Adi, S. (2013). Characterization of Flash Flood Disaster in Indonesia (Karakterisasi Bencana Banjir Bandang di Indonesia). Jurnal Sains Dan Teknologi Indonesia Vol 15(1), 42-51. Tangerang Selatan: Badan
Pengkajian dan Penerapan Teknologi . Diakses pada 20 February

Asy'ari, Q. (2018). Analisis Dampak Sosial Ekonomi Pasca Bencana Di Kabupaten Pamekasan (Studi Kasus Banjir, Longsor dan Kekeringan di Pamekasan 2007). J-MACC: Journal of Management and Accounting, 1(2), 153-168.. Diakses pada 18 February 2021

Banjir, K.. Dkk. . (2020). Masamba Flash Floods in July 2020, Meteorological Review. Jurnal sains dan Teknologi Modifikasi Cuaca Vol 21(2), 73-83. Sulawesi Selatan : BPPT (Badan Pengkajian dan Penerapan Teknologi). Diakses pada 15 February 2021

Basrowi. (2021). Analisis kondisi sosial ekonomi dan tingkat pendidikan masyarakat Desa Srigading, Kecamatan Labuhan Maringgai, Kabupaten Lampung Timur. Jurnal Ekonomi dan Pendidikan. 7(1). Yogyakarta: Universitas Negeri Yogyakarta. Diakses pada 18 February 2021

Bencana, P. (2020). Penanggulangan bencana pada tahap pascabencana menurut Undang-Undang Nomor 24 Tahun 2007 tentang penanggulangan bencana. Lex Et Societatis Vol VII (9). Manado: Universitas Sam Ratulangi. Diakses pada 7 february 2021

Goot, B. et al. (2014). multivalvular replacement and ventricular arrhythmias in a female child with congenital polyvalvular disease. world journal for pediatric and congenital heart surgery, 5(3), 463-466.. diakses pada 31 january 2021

Hapsoro, A. W. Buchori, I. (2015). Kajian kerentanan sosial dan ekonomi terhadap bencana banjir. Jurnal Teknik PWK, 4(4), 542-553.

Jusnawati, DKK. (2020). Kontribusi produksi padi sawah daerah sentra Sipilu (Sidrap, Pinrang, Luwu ) Terhadap Produksi Padi Sawah Di Sulawesi Selatan. Jurnal Agribis. 12(2):46-55. Diakses pada 18 February 2021 
Kadiri. (2014). Ibnu Khaldun Pencetus Teori Siklus. Lisan Al-Hal, 8(2), 245. Diakses pada 12 Maret 2021

Kaharuddin. (2021). Kualitatif:ciri dan karakter sebagai metodologi. equilibrium: jurnal pendidikan. Diakses pada 18 February 2021

Kitti Sihaloho Nani. (2019). Evaluasi kesesuaian lahan sawah pasca banjir bandang pada tanaman padi di Kabupaten Aceh Tenggara. Jurnal agroteknologi sains. Diakses pada 20 February 2021

Puspitasari, Dkk. (2018). Mitigasi bencana berbasis kearifan lokal di Desa Tieng, Kabupaten Wonosobo. Jurnal Geografi Lingkungan Tropik, 2 (2),42-49.. Diakses pada 18 February 2021

Soulisa, M. S. (2019). Perubahan Sosial Masyarakat Negeri Hena Lima Pasca Bencana Banjir Wae Ela Di Kecamatan Leihitu Kabupaten Maluku Tengah. Dialektika, 12(1), 57. Diakses pada 18 February 2021

Sri Wahyuni, Dkk. (2012). Tinjauan keadaan meteorologi pada banjir bandang Kota Padang Tanggal 24 Juli 2012. Jurnal Fisika Unand. Diakses pada 31 january 2021

Syaifullah MD. (2020). Kajian banjir bandang Masamba Juli 2020, tinjauan meteorologis. jurnal sains \& teknologi modifikasi cuaca. 21(2):73-83. Diakses pada 16 February 2021

Tenrigau, A. M., \& Dahlan, H. (2020). Model Governansi Manajemen Penanganan Korban Banjir: Studi Siri'na Pesse Metodologi Di Luwu Utara. JEMMA (Journal of Economic , 3(September), 181-193.

Tommi, Barus, B., \& Dharmawan, A. H. (2015).Analisis kerentanan petani terhadap bahaya banjir di Kabupaten Karawang. Jurnal Geografi, 12(2), 155-172..Diakses pada 31 januari 2021

Undang-Undang Republik Indonesia Nomor 19 Tahun (2013) Tentang Perlindungan Dan Pemberdayaan Petani. Diakses pada 31 Januari 2021

Utami, G., Minha, A., Wildayana, E., Purbiyanti, E., \& Alamsyah, I. (n.d.).
KABUPATEN OGAN KOMERING ILIR

The Impact of Flooding on a Farmer' s Social -Economy Environment in Belanti Village Sirah Pulau Padang Sub-district , Ogan Komering Ilir Regency.

\section{Skripsi :}

Fitrianti. (2018). Relokasi pemukiman warga bantaran sungai Ciliwung Di Daerah Khusus Ibukota Jakarta. Jawa Timur: Universitas Jember. Diakses pada 20 February 2021

Weliati. (2016). Perubahan Sosial Ekonomi Masyarakat Pasca Banjir Bandang Di Pasar Gompong Nagari Kambang Barat Kecamatan Lengayang Kabupaten Pesisir Selatan. Sumatra Barat: Repositori STKIP PGRI Sumatera Barat. http://repo.stkippgri-sumbar.ac.id/id/eprint/5250/. diakses pada 7 February 